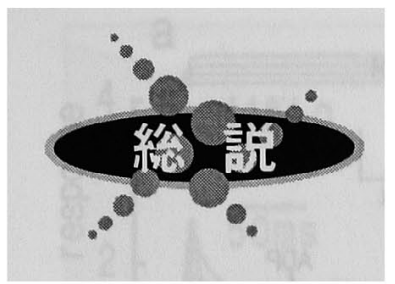

\title{
骨格筋アクトミオシン反応の「第三の中間体」と その役割
}

帝京大学医学部 岩本裕之

\begin{abstract}
The low force actomyosin complex, formed prior to force generation in skeletal muscle, has characteristics distinct from those of conventional weak- or strong-binding complexes and therefore constitutes a third class of intermediate in the ATPase reaction. Its dual strain sensitivity enables the muscle to resist an externally applied stretch by isomerizing to a forcesupporting form, while reducing excessive energy consumption during shortening by limiting the number of myosin molecules which enter the force-generating event.
\end{abstract}

Actomyosin / muscle contraction / low force complex / strain sensitivity / efficiency

\section{1.はじめに}

筋收縮とは何か? 単に筋肉が力を出す，または短縮す ることだというのは正確な答えではなかろう．筋肉は 「力発生」モードと「短維」モードをもち,この2つを うまく切り替えて,速く走ったり，物を持ち上げたり， 姿㢣を保ったり, 外力に抗して大きな張力を発生した 等, 生体の課すさまざまな要求に对応しているよう に見える.このさい必要に応じて筋肉の硬さを変えた ク、エネルギー消費速度を調節したりしている.しかも，

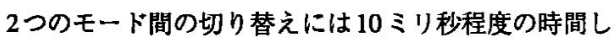
か要しない.この臨機応変の調節機能こそが笳収縮の 大きな特徽であり，その機構の解明は筋研究の最も重 要な課題の一つと言える.ささらに,この迅速な調節機能 がミオシン・アクチンというわずか 2 種頪の収縮蛋白 によって担われている点も見逃せない，筋肉の発生す る力学エネルギーはミオシン・アクチン複合体 (アク トミオシン) の営むATP加水分解反応に由来するが, 調節機能の高さの秘密はどうやらその反応の椱雑さに ありそうである.実際この反応は多くのステッブを含 んでいる(文献1その他, 图1a) . ステップの多いこと は，それだけ調節の行われる機会も多いことを意味す ろ. 多様な要求に対応する上で, 動物は筋肉に多数の蛋 白を動員する代わりに蛋白の種類を限定し，その反応 プロセスを梅雑にする方向に進化したのであろう．
アクトミオシンのATP分解反応と収綟現象は、どう 関連しているのだろうか？図1aのスキームに含まれ る反応中間体は, 従来ミオシン・アクチン間の親和性 の違いから「弱く結合した中間体」と強く結合した 中間体」に大別されてきた. 而者は親和性以外にも表 1 に示すような对照的な特徵を示すり。ミオシンのアク チンへの結合後, ATP加水分解産物の無機燐酸 $(\mathrm{Pi})$ はミオシンから離れていくが,このとき「弱く結合し た中間体」が「強く結合した中間体」に転換され，同 時に収縮力も発生すると考えられてきた.ミオシンが 筋線維の短縮を促す方向に変形して力学エネルギーを 放出し，最終的にアクチンから解離すると一回の力発 生イベントが終了する.この過程でミオシンはADPを 放出してATPを再結合する.この考えではATP分解と 力発生イベントが $1: 1$ 対応している. ADPの放出は恐 らくミオシンの短縮方向への変形とカッフルしてい て, 変形が許される条件（短縮中）では速い反応と考 えられる.したがって短維中のATP分解（エネルギー 消費）速度は高く、時間平均したミオシン1分子あた りの力は小さい。一方変形が制限された状態（長さ一 定=等尺性条件下）ではADPの放出か㧕えられ，ATP 分解速度は低く、ミオシン1分子あたりの張力が大き くなる. 前者が「短綟」モード, 後者が「力発生」モー ドというわけだが, 再者の間が連続的なのは言うまで もない.

Low force actomyosin intermediate of skeletal muscle and its role in contraction Hiroyuki IWAMOTO

Department of Physiology, School of Medicine, Teikyo University 


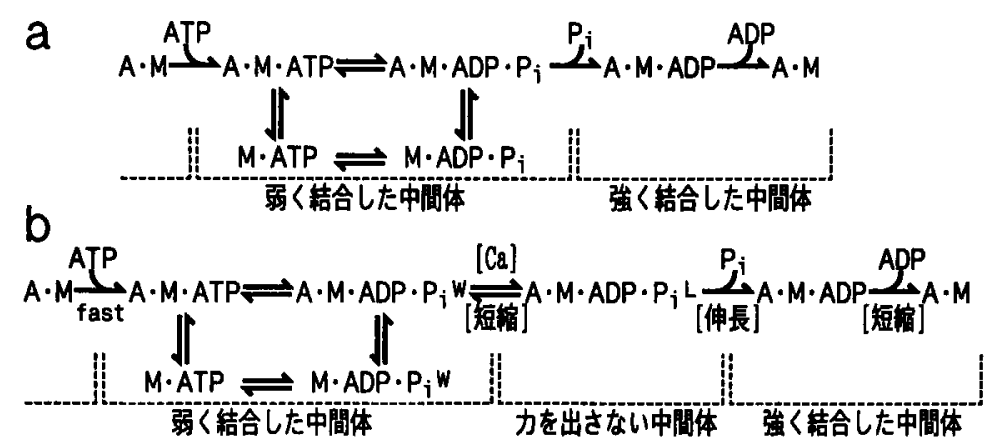

因1 アクトミオシンATP加水分解反応スキーム，(a) 従来の反応スキーム. 文载1その他のものを要約した（b）筆者の提唱する反 応スキーム、A，M，Piはそれぞれアクチン，ミオシン，無機撛酸を示す．［] で囲ったのはそのステッブを加速する因子．

表 1 弱く結合した中間体と强く結合した中間体の性䆓の比㜞．

\begin{tabular}{|c|c|c|c|c|}
\hline & 強力のサポート & $\begin{array}{c}\text { アクチン・ミオシン } \\
\text { 間の結合解離 }\end{array}$ & $\begin{array}{c}\text { regulated actin } の \\
\text { 活性化 }\end{array}$ & 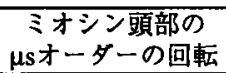 \\
\hline $\begin{array}{l}\text { 弱く結合した中間体 } \\
\text { 強く結合した中間体 }\end{array}$ & $\begin{array}{l}\text { しない } \\
\text { する }\end{array}$ & $\begin{array}{l}\text { 速い } \\
\text { 遅い }\end{array}$ & $\begin{array}{l}\text { しない } \\
\text { する }\end{array}$ & $\begin{array}{c}\text { 示す } \\
\text { 示さない }\end{array}$ \\
\hline
\end{tabular}

さて，筆者は「弱く結合しだ間体」が「強く結合 した中間体」に変換される前に,両者のいずれとも異 なる第三の中問体を経由すると主張している2，3) (図 1b）. 筆者はこれを「力を出さない中間体」と呼び, こ れが筋肉の機能を調節する上で重要な役割を演じると 考えている. 実際あとで述べるように，「力を出さない 中間体」の存在を考えると従来説明が困難だった実験 事実もうまく説明できるのである，以下に，「力を出さ ない中間体」の性質と筋収絠に対する意義を解説して みよう。

\section{2.「力を出さない中間体」の基本的性質}

$\mathrm{X}$ 線赤道反射強度や筋肉の硬さ（スティフネスと呼 ばれ，結合したミオシンの数の指標として用いられる） の湘定結果 (4) .s) から, 張力発生に先立ってミオシンが まず力を出さない形でアクチンに結合することは以前 から推測されていた.このアクトミオシンの形態は筆 者の主張する「力を出さない中間体」と恐らく同一の ものである.しかし、このアクトミオシンの形態は単に 闒く結合した中間体」そのものと見做されたり，ある いはスティフネスを示すだけの理由で「強く結合した 中間体」と見做されたりして，その性質は十分に調べ られていなかった。そこで、細胞膜を取り除いたウサギ 骨格筋線維を用いて「力を出さない中間体」が増加す るような $2 つ の$ 条件で実験を行なった結果, この中間
体が「第三の中間体」と呼よにふさわしいユニークな 性質を持っことが分かったのである.

「力を出さない中間体」が增加する条件とは，1つは 無機橉酸 $(\mathrm{Pi})$ の添加で, もう一つは䧗樎中である. 前 者は力発生のステップの平衡を逆方向に移動させ，後 者は短縮が「強く結合した中間体」の解離を加速する 結果, 力発生前の中間体か蓄積すると予想される.ステ イフネスの測定結果は、これらの条件下で張力が下が る割には結合したミオシン数が減らないことを示して Wる.

\section{1 高周波粘弦性}

このように「力を出さない中間体」が豊富に存在す る条件では，施線維に $500 \mathrm{~Hz}$ 程度の高周波の正弦波振 動を加えたときの力学応答に粘性成分が增加する2) .3)． 高周波域の粘性は，「弱く結合した中間体」のように ミオシン・アクチンが速い結合解離を綝り返す6) とき に観察される.しかしミオシン・アクチン間の解離は 䐅いので (後述)，粘性はむしろミオシンがアクチンに 結合したまま速い構造㯰らぎを繰り返すために生ずる と考えた方がよい。電子スピン共鳴法を用いれば、ミリ 秒以下の分子回転を観察できるだろう.

\section{2 伸長に対する力学応管}

Pi 存在下または短縮中の筋線維を突然引き伸ばすと， 伸長前の張力レベルの割に大きな力学応答を示す2) (3) (図2).引っ張りに对しては「力を出さない中間体」も 


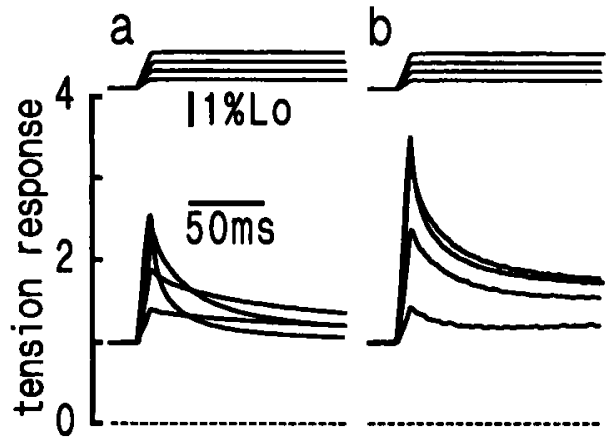

国2 定速伸長に对す万筋線䧽の力学応答. (a) コントロール。 (b) $20 \mathrm{mM}$ Pi 存在下，伸长 (上のトレース) の期間は 10 $\mathrm{ms}$ で，振幅が筋線維长の $0.3 ， 0.6,0.9,1.2 \%$ 場合の記 録を重ねた. 張力応答（下のトレース）は伸長前の張力 レベルで正規化した（文献2より踇可を得て転載）。

「强く結合した中間体」並みの抵抗を示すようである． 大きな力学応答とともに高周波の粘性成分は失われる. 生筋を刺激直後, また張力の小さいころに数\%引つ張 ると突然大きな張力を発生するが (A.V. Hillの有名な active state $の$ 実験），これは収縮初期に「力を出さない 中間体」が豊富に存在することで説明できるク．

興味深いことに, 大きな力学応答は筋線維長の $0.3 \%$ 以上, ミオシン分子あたりにして約4 nm 以上の伸長で 初めて観察され，それ以下ではコントロールと変わら ないのである（図2）.したがって伸長の振幅に対し力 学応答の大きさをプロットすると（伸長一応答曲線）， $4 \mathrm{~nm}$ のころに明暸な屈曲点をもった非線型な曲線に なる2)(図3a).「力を出さない中間体」は遅い長さ変 化に対しては柔らかいが, $4 \mathrm{~nm}$ の臨界変形を受けると カを支えるような構造に変化 (isomerization) するの であろう.

\section{3 解離の速度}

上記の伸長実験で，伸長を次第にゆっくりにしてい けば「力を出さない中間体」は4nmの臨界変形を受け る前に解離し, 非線型性は失われていくであろう.これ から「力を出さない中間体」の解離速度が推定できる。 Pi 存在下では, 伸長に $100 \mathrm{~ms}$ 以上かけても非線型性は 依然として残り,解離の速度定数は約 $10 s^{-1}$ と見積も られた2).この值は「弱く結合した中間体」の場合 $\left(10,000 \mathrm{~s}^{-1}\right)^{6)}$ より摆かに小さい.

一方短䌕中は解離がここまで遅いと，「力を出さな い中間体」はアクチンに結合したまま引きずられ，短 縮を妨げてしまう。しかし「力を出さない中間体」の 短縮方向への変形が一定の值に達したときに解離が起 こればこの問題は回避できる.この一定值に達する速

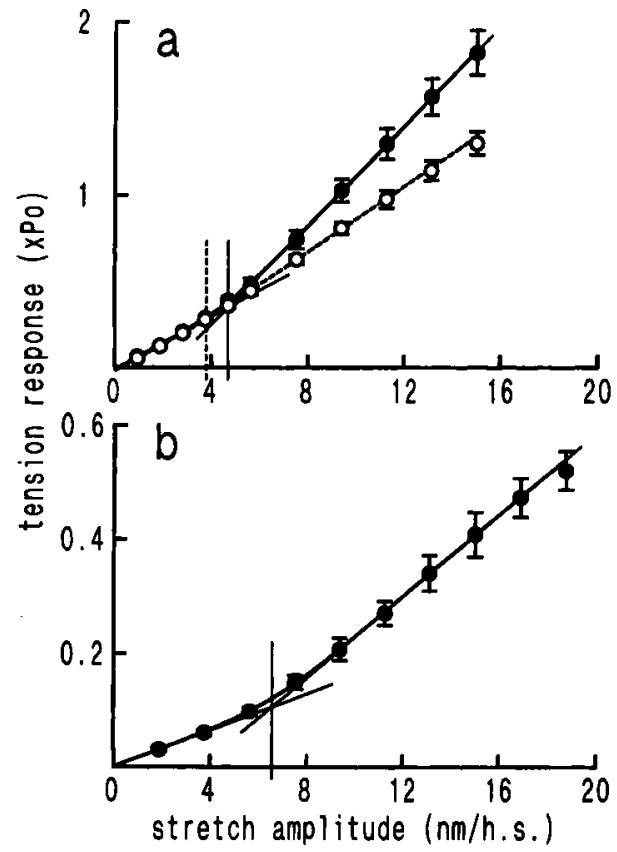

图3伸長の振幅と力学応答の大きさとの関係，(a) 等尺性収 缩時に伸展. $20 \mathrm{mM} \mathrm{Pi}$ 存在下（黒丸）上非存在下（白 丸）（b）等尺性張力の $30 \%$ の荷重で短縮時に伸長. 伸 辰の振幅はミオシン 1 分子あたり，応答の大きさ恃等尺 性張カレベルあたりで示す (文献了より改変)

さは短縮速度に比例するので，「力を出さない中間体」 の解離も短縮速度に比例して加速することになる，そ して実験結果はこの考えを支持した.

短縮中には,この短縮方向の変形を上記の $4 \mathrm{~nm} に$ 加 えた大きさの伸長を加えたときに初めてミオシンが臨 界変形に達する。したがって伸長-応答曲線の届曲点に はこの変形の大きさが加算されてくる. 等尺性張力の

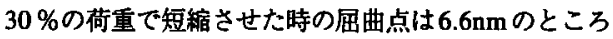
にあり（図3b），等尺性時に比べ2.8nmの加算である． このときの滑り速度 $\left(260 \mathrm{nms}^{-1}\right)$ をこの值で割って 求めた解離速度定数 $\left(90 \mathrm{~s}^{-1}\right)$ は, 確かに等尺性条件下 より大きい3)，そして変形の大きさは短縮速度にほと んど依存せず，「力を出さない中間体」の解離は短縮 速度にほほ比例して加速することが示された，無荷重 短縮時には，解離速度定数は $300 \mathrm{~s}^{-1} に も$ 達する計算に なる、解離が加速されるのは，短縮方向の変形がアクチ ン・ミオシンの各結合サイト間の距離を增すように働 くためであろう .

以上を総合すると，「力を出さない中間体」が「弱 く結合した中間体」や「強く結合した中間体」にはな 
いユニークな性質を持つことは明らかである（表1参 照) . 疲労時 (Piが蕃積する) p収縮初期で発生張力 が小さいときでも外部から伸長を受ければ速やかにこ れに抵抗し，短縮時には速や加に外れて短縮速度を保 証する、一種のラチェットとして锺くわけである.

\section{3.「力を出さない中間体」の筋收粳に対する意垶}

冒頭で述べたように, 従来の考えでは力発生イベン トからの出口，すなわちADP放出が筋肉のパフォーマ ンスを決定する主な力学感受性ステップであった，し かしこれまでの筫論で, 力発生イベントへの入りロに おいて「力を出さない中間体」が二通りの力学感受性 ステップを提供することを説明した（伸長に伴う構造 変化と短縮に伴う解荿：図1b).このうち,短縮に伴う 解離はすでに力発生イベントに入った「強く結合した 中間体」の起こす滑り運動によって，まだ力を発生し ていない他のミオシンの力発生イベントへの新規参入 が制限されることなので, 一種の負の協同性というこ とができる.以下に, 特にこの負の協同性のもつ意味に ついて述べてみよう。

短縮速度を增すと張力とスティフネスはともに減少 するが, 最大短縮速度（無荷重；通常数 $\mu \mathrm{ms}^{-1}$ ) でも 等尺性收宿時の $40 \%$ \%スティフネスが残るといわれ

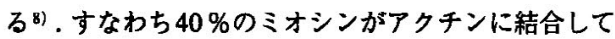
いるわけだが, ミオシン頭部のサイス ( 20nm) を考 えれば一個のミオシンが結合していられる時間恃わず かである.したがってミオシンの解離ごとにATPを壊 していたら，ATP消費速度は非常に高くなってしまう， ところが実際の最大短緶速度でのATP消費速度は予 想よりかなり低く，わずか数\%のミオシンしか結合し ていない計算になる゙．この矛盾を説明するため, ATP 分解なしに強く結合したミオシンの解離が起こる(一 回のATP分解で力発生イベントが何回も起こる）と いう考えが提出されている9．しかしこの矛盾は，結合 したミオシンがすべて「強く結合した中間体」である との暗默の仮定から生じたもので, 負の協同性を考え れば矛盾は容易に解決する。すなわち最大短綟速度て は「力を出さない中間体」は結合解離を繰り返し，な かなか力発生イベントに入れないだろう.すると結合 したミオシンの大部分は「力を出さない中間体」のま まで，「強く結合した中間体」はわずかとなり，ATP 消費速度も低下することになる3（図4,5)。「強く結 合した中間体」は実際に数\%程度になると計算され る。また「强く結合した中間体」の全ストローク（能 動十受動) は約40nm と予想され，ミオシン頍部のサ イス $(20 \mathrm{~nm})$ と矛盾しない. Brenner もまったく独立

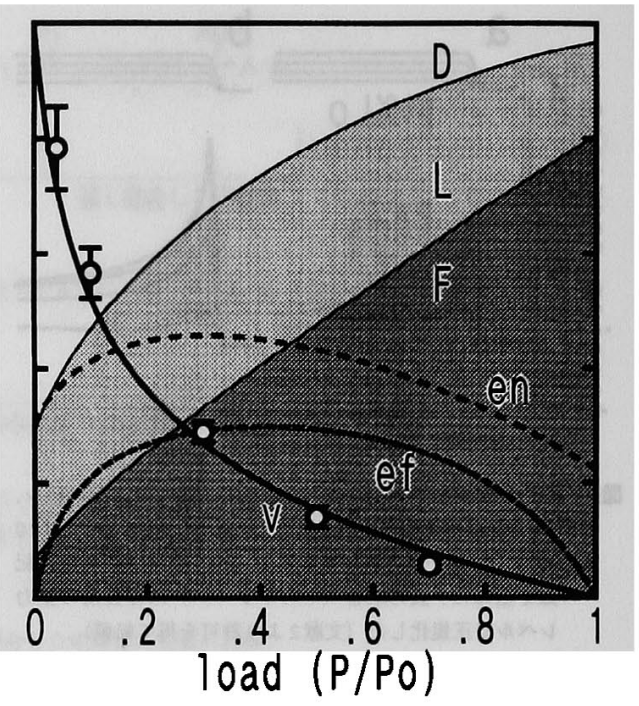

图4負の協同性を考后に入れたときの中間体分布と収維の工 ナジェティクス．各中間体の分布（D，弱く結合した；L, 力を発生しない；F，強く結合した中間体），ATP消筫速 度 (en)，奻辛 (ef)，短縮速度 (v) の荷重依存性。短縮 が非常に速くなると，ATP消坣速度が却って娍少するこ とに注意。しし負の協同性がなければ単調に增加する (文献了より研可を得て䎐載)
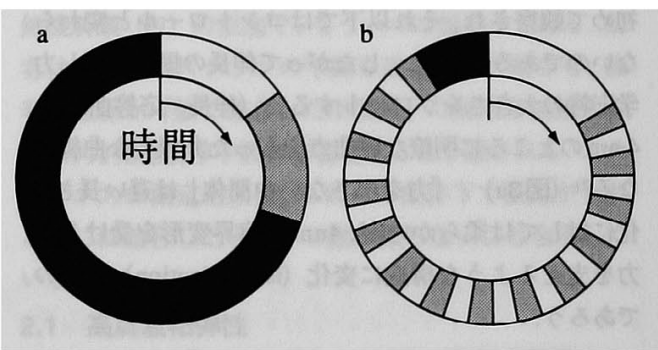

図5アクトミオシン反応サイクルの時間配分（（a）「力発生」 (等尺性) モード，(b)「短縮」モード.「力発生」モード では「力を出さない中間体」(網) はあまり解踓（白）す ることなく「强く結合した中间体」(黒)に移行し、喆合 時問の大部分を後者として遇ごす．「短縮」モードでは 「力を出さない中間体」は「強く桔合した中間体」に移行 する前に結合解䭛を繰り返し，結合時間の大部分を前者 として過ごす。

の実験から最大短縮速度で「強く結合した中間体」が 少ないと述べている10)。

以上の議論は、ミオシンをコートしたガラス面上を わずか40nmの短いアクチンフィラメントが高速で滑 るというインビトロ系での観察11)と矛盾するように見 える.しかしこのような短いフィラメントでは負の協 


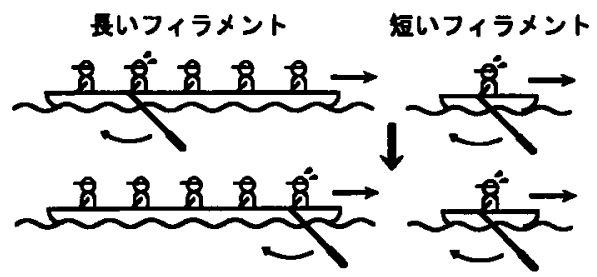

图6 インビトロアッセイ系における負の協同性.アクチンフィ ラメントの消りを低レイノルス数の池でのボート㜔技に 例えてみた. 個々のクルーは一人でボートを高速で推進 するのに十分な力を持っことにする、ボート（フィラメ ント)が長い堨合は同時に一人だけ䜺いでいればボート は高速で進むので他のクルーはサボり，ATP消費は少な くなる、しかしクルーが一人の埸合は常に消导䅧けなけ れば（ATPを分解し繶けなければ）ボートは止まってし まう。

同性は㗢かず, ATP消費速度は長いフィラメントの場 合より高いと予想される（図6）。

また負の協同性は,筋線維のATP消費速度と, 可溶 化した収䑿蛋白（F-アクチンとミオシン頭部断片）の 溶液系でのATP消費速度との関係にも示唆を与える. 笳線維中では上に述べたように，等尺性取縮時と無荷 重短樎時は，いずれも収維蛋白がフィラメント上に固 定されているために生じる制限がATP消費速度を抑え ることになる.一方溶液系ではそのような制限が存在 しないので, ATP消費速度は系が取りうる最大值とな ろであろう. 溶液系のATP消費速度は、、オシンから のADP放出が促され，しかも負の協同性があまり働か ない中間的な短縮速度での值に最も近いと思われる゙)。

\section{4. 桔知}

筋線維中のアクトミオシンは, 䙁雑なATP分解反応 経路の特定のステップを調節することにより，その直
かれた力学条件に迅速に対応しているようにみえる。 その調節は、従来考えられたように力発生イベントの 出口だけでなく, 入り口でも行われている.その重要な 立役者として「力を出さない中間体」をクローズッ プした．「力を出さない中間体」は,外的な伸長に対す る迅速な抵抗を可能にし，短縮時にはATP消費速度を 制限してエネルギー変換効率を上げるのに役立つと思 われる．「力を出さない中間体」を考虑に入れれば1： 1对応型のモデルで特に矛盾は生じない.さらに「力を 出さない中間体」は,カルシウムによる収縮弛紘の制 御点でもあることが最近の結果から示されている(2)。

\section{文献}

1) Ostap, E. M., Barnett. V. A., Thomas, D. D. (1995) Biophys. J., 69, 177-188

2) Iwamoto, H. (1995) Biophys.J., 68, 243-250.

3) Iwamoto, H. (1995) Biophys.J., 69, 1022-1035.

4) Cecchi, G., Griffiths, P. J., Taylor, S. (1982) Science, 217, 70-72.

5) Huxley, H. E. (1975) Acta Anat. Nippon, 50, 310328.

6) Schoenberg, M. (1988) Biophys.J., 54, 135-148.

7) Iwamoto, H., Kobayashi, T., Amemiya, Y., Wakabayashi, K. (1995) Biophys.J., 68, 227-234.

8) Homsher, E., Irving, M., Wallner, A. (1981) J. Physiol., 321, 423-436.

9) Julian, F. J. Sollins, M. R. (1975) J. Gen. Physiol., 66, 287-302.

10) Stehle, R., Kraft, T., Brenner, B. (1993) Biophys.J., 64, A250.

11) Harada, Y., Sakurada, K., Aoki, T., Thomas, D. D., Yanagida, T. (1990) J. Mol. Biol., 216, 4968.

12）岩本裕之（1995）生物物理, 35, S213. 